\title{
Effect of Conservation Agriculture Practices on Chemical Properties of Soil at Assosa, Western Ethiopia
}

\author{
Dessie Almaw Cherie \\ Ethiopian Institute of Agricultural Research (EIAR), Assosa Agricultural Research Center (AsARC), Assosa, Ethiopia
}

\section{Email address:}

dalmaw121@gmail.com

\section{To cite this article:}

Dessie Almaw Cherie. Effect of Conservation Agriculture Practices on Chemical Properties of Soil at Assosa, Western Ethiopia. World Journal of Applied Chemistry. Vol. 6, No. 2, 2021, pp. 12-18. doi: 10.11648/j.wjac.20210602.11

Received: May 15, 2021; Accepted: June 21, 2021; Published: June 26, 2021

\begin{abstract}
Conservation agriculture is a crop production system that retains an everlasting soil cover through preservation of crop residues on soil surface with zero and reduced till to enhance natural biological processes. It is also a way of organizing agricultural ecosystems for continued and greater sustainable productivity. Not only sustain agricultural productivity; plants, animals and human health are soil quality dependent. However, conventional agricultural practices have reduced soil productivity at such a scary rate, many agricultural soils are leached-out of nutrients and unable to naturally sustain crops. Determining impact of conservation agriculture on soil chemical properties at Assosa district was chosen to study chemical supplement substances of the soil from CA. This study pointed to assess the impact of distinctive conservation agriculture on soil chemical properties such as $\mathrm{pH}, \% \mathrm{OC}, \% \mathrm{TN}, \mathrm{mg} / \mathrm{kg}$ soil of phosphorus, meq $/ 100 \mathrm{~g}$ of soil exchangeable acidity, meq $/ 100 \mathrm{~g}$ of soil potassium and CEC at the research site. Chemical parameters analysis were done using AOAC methods. All soil tests collected from the treatment confirmed recognizable difference among the treatment and year. Despite that, in all analysis centrality distinction of soil organic carbon and total nitrogen within the soil showed better result in conservation agriculture and uncovered land than the conventional one. The $\mathrm{pH}, \% \mathrm{TN}, \mathrm{mg} / \mathrm{kg}$ of $\mathrm{P}$, meq $/ 100 \mathrm{~g}$ soil $\mathrm{K}, \% \mathrm{OC}, \mathrm{CEC}$ and exchangeable acidity were assessed three times in two years interval. The chosen location soil was as well disintegrated and unequivocally acidic.
\end{abstract}

Keywords: Cation Exchange Capacity, Conservation Agriculture, Conventional Agriculture, Soil, Soil Organic Matter, Soil $\mathrm{pH}$

\section{Introduction}

Soil erosion is one of the main agro ecological and environmental problems that make threats agriculture in Africa and other parts of the world [1]. The problem is becoming increasingly more disturbing in developing countries including Ethiopia where majority of the population are agriculture dependent. The average rate of soil erosion from cultivated land in Ethiopia has been estimated to be 42 tons $\mathrm{ha}^{-1} \mathrm{yr}^{-1}[2,3]$, which is by far in excess of the mean annual soil loss tolerance value of 5 to 11 tons $\mathrm{ha}^{-1}$ which is generally accepted as acceptable rate of soil erosion though this value can be as low as 2 tons $\mathrm{ha}^{-1}$ for particularly susceptible areas where soils are thin or highly erodible [4].

Conservation agriculture practice is a crop production system that remains a permanent soil cover through conservation crop residues on the surface of soil with reduced and zero tillage to increase biological processes above and below the soil, [5] and defined as management of soil, water and agricultural resources to achieve economic and ecological sustainable agricultural production practice than narrowly defined conservation tillage [6]. It is also a basis of soil fertility improvement [7] and soil fertility is a determinant of agricultural sustainability. In general, plant, animal and human health can be described as integration of physical, chemical and biological properties of soil for their production [8].

Continuous cultivation, removal of crop residues and wild fire, intensive tillage, mono cropping system and poor soil management leads to soil fertility decrement. Therefore; conservation agriculture has the potential to enhance soil organic matter content, decrease soil loss, increase soil nutrient availability and quality for plant and save costs than tillage based agriculture [9].

Conventional farming practices have reduced soil productivity since agricultural soil nutrients are washed-out 
and unable to naturally sustain crops productivity $[10,11]$. This infertile soils that formed by conventional practices can be rehabilitated into fertile and healthy soil for yields increments [12]. Crop diversification, minimum soil disturbance, and permanent soil cover are the three main conversion principles applied in ecological oriented conservation agriculture used to increase and sustain soil organic matter and soil health [13].

Tillage frequency, crop rotation and residue management practices had significant effect and influence on soil $\mathrm{pH}$, soil organic matter, nitrogen contents, exchangeable cat-ions distribution and its transformation [14, 15]. Soil bulk density affects the root dissemination and soil aeration which has important role in crop growth and development. Soil strength and porosity is a result of bulk density and had significant effects on plant growth. Soil bulk density also depends on soil texture, mineral content, soil structure, organic matter, type of crops and management practices [16].

\section{Soil Chemical Quality and CA}

\subsection{Soil pH}

Soil $\mathrm{pH}$ is one of the most common measurements in soil laboratories. It reflects weather a soil is acidic, neutral, or basic/alkaline. It is more correctly defined as the negative logarithm of the hydrogen ion activity $\left(\mathrm{pH}=-\log ^{[\mathrm{H}+]}\right)$, since the $\mathrm{pH}$ is logarithmic; the hydrogen ion concentration in solution increase ten times when the $\mathrm{pH}$ is lowered one unit. The fertility of soil decreases with declining $\mathrm{pH}$ that can be induced by acidifying nitrogen fertilizer, and conventional agricultural practices [17]. Soil $\mathrm{pH}$ change can also be caused by natural processes such as decomposition of organic matter and leaching of cations. The lower the cation exchange capacity of a soil, the faster the soil $\mathrm{pH}$ will decrease with time [18].

\subsection{Soil Organic Matter (SOM)}

Soil organic matter is a measure of soil quality and central indicator of agricultural production sustainability. Rehabilitation of soil organic matter is a basic activity to improve soil quality and food security in addition to counterbalance of the negative impact of agricultural related climate change [19]. Although the rate is climate dependent, intensive tillage practices increases oxidation of soil organic carbon and leading to lower soil organic carbon content over time. Conservation agriculture practices reduce soil organic carbon oxidation by decreasing soil integration. Formation of higher soil micro-aggregates under CA is considered as major mechanism of carbon sequestration in soil [20]. Carbon sequestration accountable when net addition of SOC through crop residues exceed carbon removal in term of crop harvest, microbial respiration, carbon emissions from fuel and the manufacture of chemical fertilizers. Therefore; to achieve positive carbon stock in the soil, we must need to either increased carbon inputs to the soil, decreased oxidation of
SOC, or a combination of both [21].

\subsection{Available Phosphorus}

A proper amount of phosphorus is essential for keeping up an adjustment between plant supplements and guaranteeing the normal growth of crops. The availability of phosphorus in soil is too variable since it depends on the mineral soil composition, organic materials and its rate of decay decomposition, neighborhood climatic conditions and the morphological properties of soil [22].

\subsection{Cation Exchange Capacity (CEC)}

Potassium, magnesium, sodium, calcium, ammonium $\left(\mathrm{NH}_{4}{ }^{+}\right)$cat ions magnetize and hold with negatively charged ions within the soil. Cation exchange is a reversible process. In this way, nutrients or supplements can be detained within a soil, not misplaced during leaching, and can in this way be released for crop take-up. Certain organic compounds supply cation exchange capacity (CEC) to the soil. The course of action is known as cation exchange capacity (CEC) of soil [23].

Cation exchange capacity (CEC) is a measure of soil's ability to hold positively charged ions. It is an imperative soil property influencing structure stability of soil, nutrient accessibility, soil $\mathrm{pH}$ and soil's reaction to fertilizers and other ameliorants [24].

\section{Materials and Methods}

\subsection{Study Area}

The experiment was conducted at Assosa agricultural research center research site which is located in Benshangul Gumuz regional state, Western Ethiopia. It is located $10^{\circ} 30^{\prime} \mathrm{N}$, latitude and $034^{\circ} 20^{\prime} \mathrm{E}$ longitude, an altitude of 1665 m.a.s.l with unimodal and $1275 \mathrm{~mm}$ mean annual rain fall. The minimum and maximum temperature is vary between $14{ }^{\circ} \mathrm{C}$ and $39^{\circ} \mathrm{C}$. The farming system in the region is a mixed farming system with both crop and livestock. The slop gradient of study area and soil type is $6.5 \%$ and reddish brown nitisols respectively.

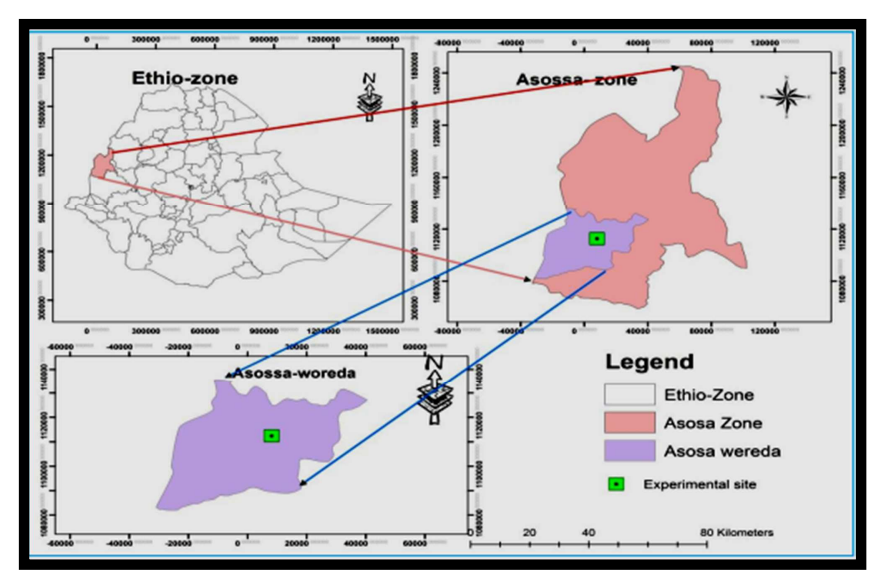

Figure 1. Experimental site map location. 
Table 1. Experimental layout.

\begin{tabular}{ll}
\hline Treatments & Treatment Description \\
\hline T-1 & Conventional practice: Soybean-maize rotation without residue retained \\
T-2 & Bare land: Keep bare by regular weeding \\
T-3 & Conservation Agriculture (Zero tillage): Soybean-Maize rotation with residue retained \\
\hline
\end{tabular}

Soil samples were collected from three triplicates treatments.

\subsection{Materials}

Triplicate soil samples for each treatment, $\mathrm{pH}$ meter (model No pH-016 Bench top pH meter), Spectrophotometer (model No DU 8800R), Flame photometer (model No PFP7), Digital burette (model No 16G10518), Kjeldhal nitrogen distiller and digester, and electronic balance (model No $1 \mathrm{~A} 11003 \mathrm{~N}$ ) were materials used for experimental analysis.

\subsection{Soil Sample Collection and Preparation}

Representative composite soil samples were collected three times, i.e. before experiment applied, at the third year of the experiment and after experiment was completed at depth of 0 $30 \mathrm{~cm}$ from 3 triplicate treatments which are represented by Treatment-1 (T-1) to Treatment-3 (T-3) for this study. The collected soil samples were removed and freed from rubble, stones and air dried, ground and sieved in 1, and $2 \mathrm{~mm}$ sieve size and then mixed thoroughly to obtain a homogeneous representative sample mixture. The sieved soil samples were packed and sealed in an airtight plastic cover and ready for nutrient analysis. Chemicals/reagents and solvents used in the laboratory analysis were analytical grade.

\subsection{Methods of Experimental Analysis}

The $\mathrm{pH}$, percent of organic carbon, percent of total nitrogen, $\mathrm{mg} / \mathrm{kg}$ of available phosphorus, meq $/ 100 \mathrm{~g}$ of soil cation-exchange capacity, potassium, and exchangeable acidity of collected soil samples were decided by $1: 2.5$ soil to water proportion, Walkley-Black method, micro kjeldhal method, Bray II method, ammonium acetate extraction with micro kjeldhal method, $1 \mathrm{~N} \mathrm{NH}_{4} \mathrm{OAc}$ extraction with flame photometer method, and $1 \mathrm{~N} \mathrm{KCl}$ extraction with titration methods individually [25].

\subsection{Data Analysis}

All analyzed soil parameters were measured in triplicates. All necessary standard calibration curves for analysis were constructed using Microsoft office excel 2007. Statistical analysis was also taken by analysis of variance (one way ANOVA) with Least Significant Difference (LSD) to compare result between treatments and years using SPSS statistics version 20. Result was considered statistically significant at $\mathrm{P}$-value $<0.05$.

\section{Results and Discussion}

The chemical observations of three triplicate soil samples were presented in Tables 2 and 3. The result verifies that the soil sample from respective years and treatment have noticeable significant variations each other in chemical properties specially soil $\mathrm{pH}, \% \mathrm{OC}, \% \mathrm{TN}$, and meq/100g of soil exchangeable acidity.

\subsection{Soil PH and Organic Matter}

The ideal recommended optimum $\mathrm{pH}$ range for plants growth is 6.5 to 7.5 [26], however $\mathrm{pH}$ of eroded selected site soil samples were found in range of very strongly acidic. The $\mathrm{pH}$ of soil is one of the most important parameter, but the study area was too acidic which had even had less than $4.5 \mathrm{pH}$ value. The soil $\mathrm{pH}$ of conservation agriculture treatments were increased as compared with that of conventional practiced one. The result showed that the content of soil organic matter in the conservation agriculture plots positively correlation with $\mathrm{pH}$ value of the sample and confirmed the previous research work [27]. A positive and good correlation between soil organic matter and $\mathrm{pH}$ in the study implies that the soil organic matter content has persuade on the acidity of the soil. When a soil organic matter has increased, the acidity of the soil decreases, because the carboxyl groups on the humus develop negative charge and suppress the positively charged hydrogen $\left(\mathrm{H}^{+}\right)$that reacts with the hydroxyl $\left(\mathrm{OH}^{-}\right)$to form water [28].

\subsection{Soil Chemical Properties}

The result of soil chemical properties of collected soil samples from respective treatments and years have noticeable significance variations each other in $\% \mathrm{OC}, \% \mathrm{TN}$, exchangeable acidity in meq/100g of soil content between conventional and conservation agriculture practices. All chemical properties of the collected soil samples before practiced had no statistical significant difference. The selected site was sloppy, eroded, intensively farming practiced and free grazing area; the effect of this activities might be cause of reduced soil quality and nutrient disrupted and thus organic matter decrement consequence is raised of soil acidity.

Organic matter and total nitrogen of the conventional and conservation agriculture practices result had significance difference among the treatments in different year intervals. Percent of soil organic carbon ranges from conventional practice 0.767 to bare land $1.184 \%$. Initial study area soil organic carbon was remarkably low and increase its conservation practice organic carbon whilst decrease the conventional practice from the initial one. This shows conventional agricultural practice reduces microbial biomass and nutrient mineralization moreover it implies soil organic carbon reduction, the reason might be scarcity of energy sources by intensive agricultural practice and soil erosion [29]. Soil organic carbon and total nitrogen results in less diversity in soil biota with a threat of the food chain equilibrium being disrupted which can cause interruption in the soil environment. 
Tables 2 and 3 result show percent of total nitrogen for collected soil samples ranged between conventional practiced of 0.081 to 0.130 conservational practices. The highest and lowest value percent of total nitrogen was recorded for bare land and conventional practice treatment respectively. The $\mathrm{mg} / \mathrm{kg}$ of available phosphorus results of this study practice was varied between 8.879 of conventionally practiced to 11.03 $\mathrm{mg} / \mathrm{kg}$ soil of conservational practiced treatments. Also, cation exchange capacity (CEC) ranges between 10.362 to 14.863 meq $/ 100 \mathrm{~g}$ soil. The highest CEC value was recorded for zero tillage Soybean-Maize rotation. While the result showed statistical significant difference, it was not highly significant as compared to soil $\mathrm{pH}$, organic carbon and total nitrogen.

Nearly in all analyzed soil samples highest value of $\mathrm{pH}, \% \mathrm{TN}, \mathrm{mg} / \mathrm{kg} \mathrm{P}$, and \%OC were recorded at bare land followed by zero tillage Soybean-Maize rotation and the least value of the data recorded at conventional agricultural practice. The laboratory analysis result of zero tillage soybean-maize rotation and bare land showed statistically non significant between two treatments.

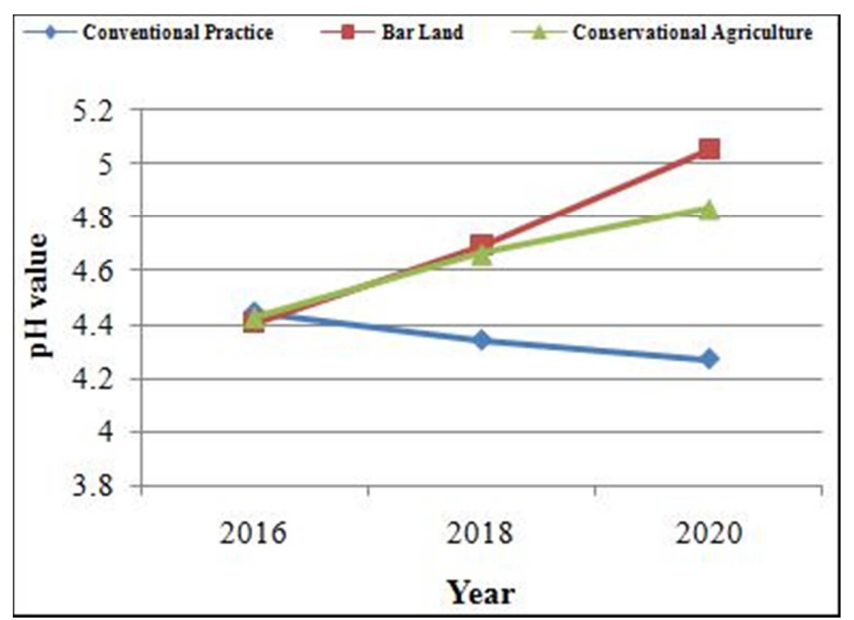

Figure 1. Effect of three agricultural practices and year interaction on soil pH at 0-30cm soil layer in 2016-2020.

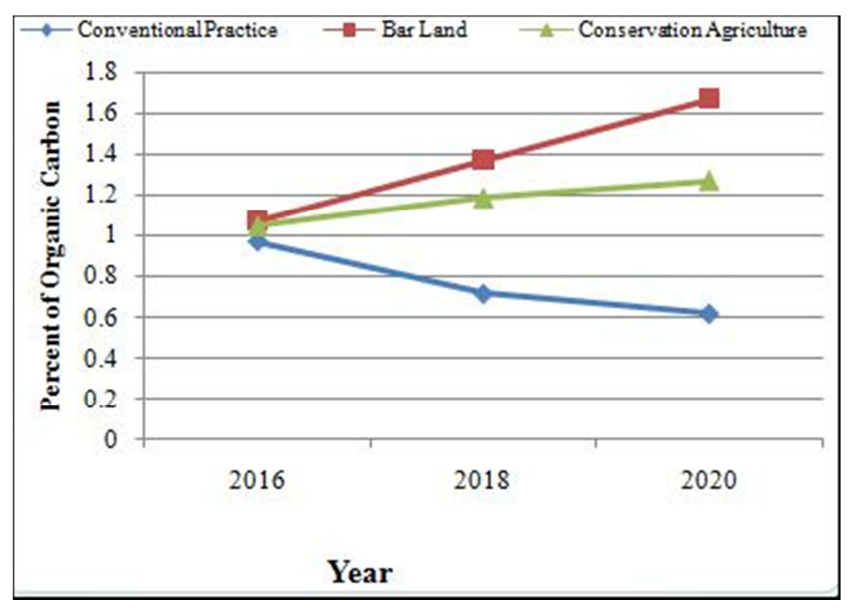

Figure 2. Percent of organic carbon changes at $0-30 \mathrm{~cm}$ soil layer of three agricultural practices in 2016-2020.

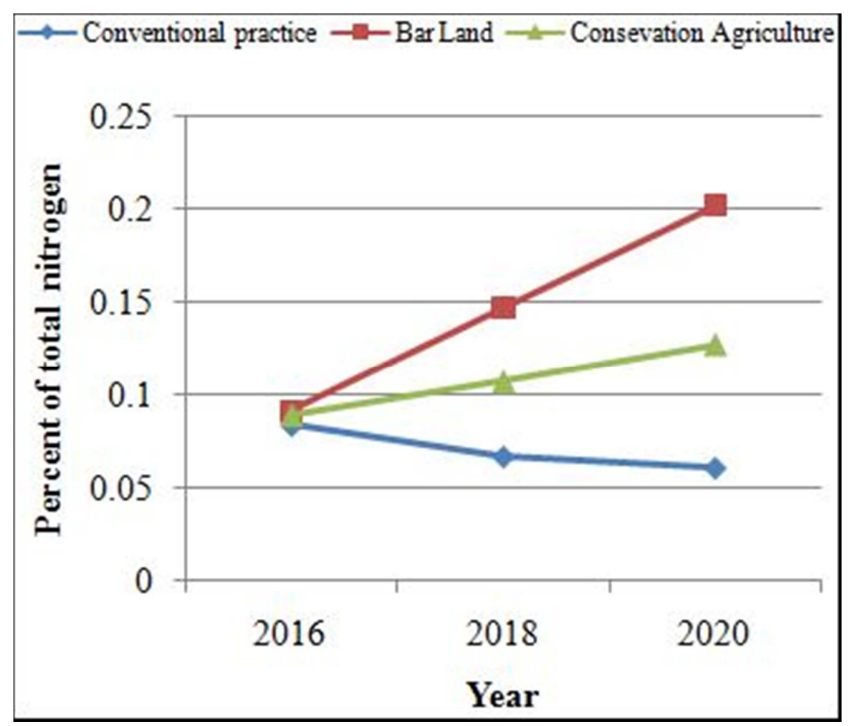

Figure 3. Effect of conservation agriculture and conventional agriculture practices with year interaction on soil total nitrogen at $0-30 \mathrm{~cm}$ soil depth..

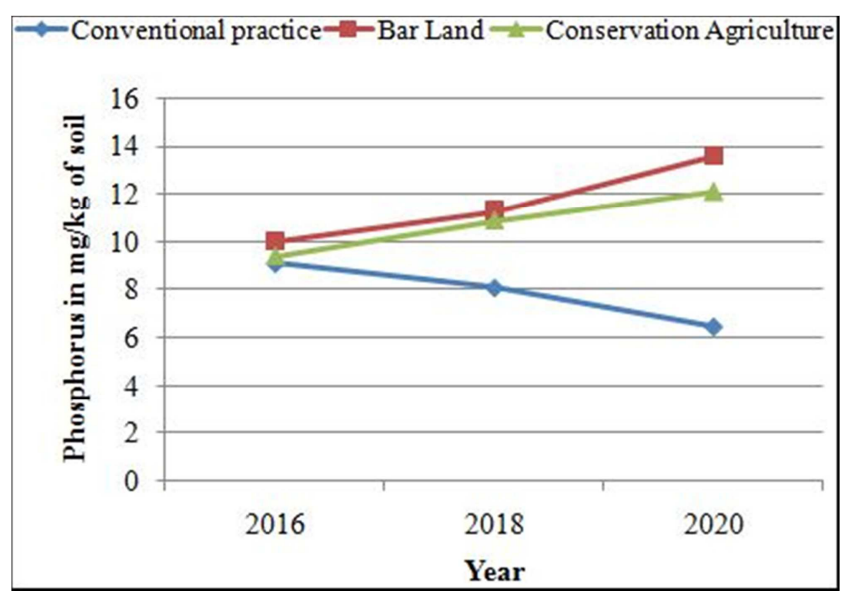

Figure 4. Available phosphorus changes in $0-30 \mathrm{~cm}$ soil depth of three agricultural practices in 2016-2020.

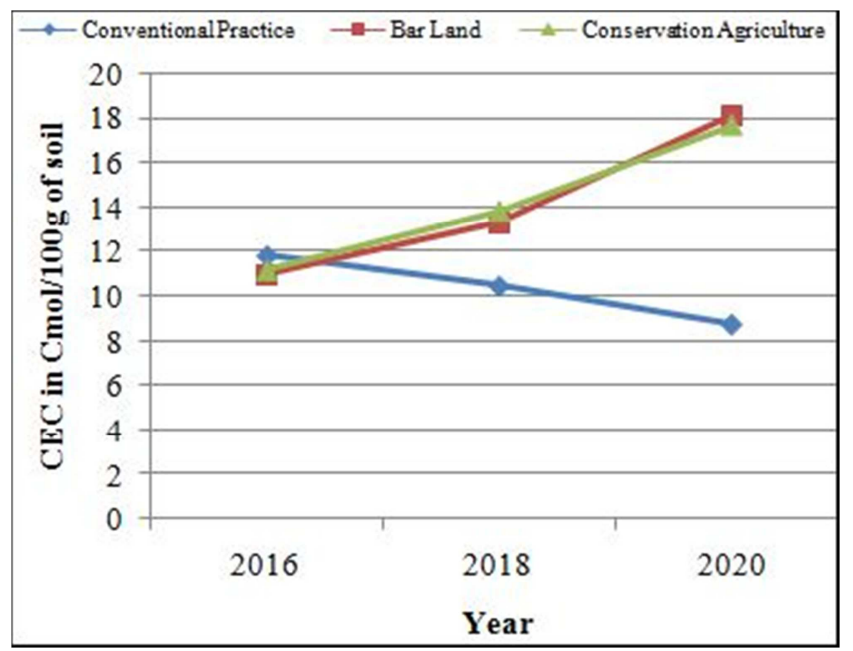

Figure 5. Effect of three agricultural practices and year interaction on soil cation exchangeable capacity at 0-30cm soil layer. 
Table 1. Overall years with each treatment soil chemical parameters interaction.

\begin{tabular}{lllllllll}
\hline & Treatment & $\mathbf{p H}$ & $\mathbf{\% O C}$ & $\mathbf{\% T N}$ & $\mathbf{~ m g} / \mathbf{k g}(\mathbf{P})$ & $\mathbf{( K )}$ in meq/100g soil & $(\mathbf{C E C})$ in meq/100g soil & Ex. Acidity in meq/100g soil \\
\hline & T-1 & $4.35^{\mathrm{c}}$ & $0.767^{\mathrm{c}}$ & $0.081^{\mathrm{c}}$ & $8.879^{\mathrm{c}}$ & $0.256^{\mathrm{c}}$ & $10.362^{\mathrm{c}}$ & $2.064^{\mathrm{a}}$ \\
& $\mathrm{T}-2$ & $4.71^{\mathrm{a}}$ & $1.18^{\mathrm{a}}$ & $0.126^{\mathrm{a}}$ & $11.603^{\mathrm{a}}$ & $0.312^{\mathrm{a}}$ & $12.121^{\mathrm{ab}}$ & $1.600^{\mathrm{c}}$ \\
Year & $4.64^{\mathrm{b}}$ & $1.106^{\mathrm{b}}$ & $0.108^{\mathrm{b}}$ & $10.778^{\mathrm{b}}$ & $0.304^{\mathrm{ab}}$ & $12.237^{\mathrm{a}}$ & $1.766^{\mathrm{b}}$ \\
& T-3 & 4.57 & 1.018 & 0.105 & 10.420 & 0.291 & 11.573 & 1.810 \\
& Mean & $* *$ & $* *$ & $* *$ & $* *$ & $*$ & $*$ & $* *$ \\
& LSD & $* *$ & & 9.078 & 12.989 \\
\hline
\end{tabular}

Table 2. Overall Treatments with each year interval soil chemical properties interaction result.

\begin{tabular}{lllllllll}
\hline & Year & $\mathbf{p H}$ & $\mathbf{\% O C}$ & $\mathbf{\% T N}$ & $\mathbf{~ m g / k g}(\mathbf{P})$ & $\mathbf{( K )}$ in meq/100g soil & (CEC) in meq/100g soil & Ex. Acidity in meq/100g soil \\
\hline \multirow{6}{*}{ Treatment } & Y-1 & $4.42^{\mathrm{c}}$ & $1.030^{\mathrm{c}}$ & $0.088^{\mathrm{c}}$ & $9.490^{\mathrm{c}}$ & $0.282^{\mathrm{b}}$ & $11.317^{\mathrm{c}}$ & $2.038^{\mathrm{a}}$ \\
& Y-3 & $4.56^{\mathrm{b}}$ & $1.089^{\mathrm{b}}$ & $0.107^{\mathrm{b}}$ & $10.072^{\mathrm{b}}$ & $0.296^{\mathrm{a}}$ & $12.541^{\mathrm{b}}$ & $1.913^{\mathrm{b}}$ \\
& Y-5 & $4.72^{\mathrm{a}}$ & $1.184^{\mathrm{a}}$ & $0.130^{\mathrm{a}}$ & $10.699^{\mathrm{a}}$ & $0.295^{\mathrm{a}}$ & $14.863^{\mathrm{a}}$ & $1.679^{\mathrm{c}}$ \\
& Mean & 4.57 & 1.101 & 0.108 & 10.087 & 0.291 & 12.907 & 1.877 \\
& LSD & $* *$ & $* *$ & $* *$ & $* *$ & ND & $* *$ & $* *$ \\
& \%CV & 3.287 & 7.057 & 19.414 & 5.994 & 2.684 & 13.955 & 9.711 \\
\hline
\end{tabular}

NB:- Y-1, 3, and 5 is represented Year-1, Year-3 and Year-5 respectively as well as $\mathrm{pH}, \% \mathrm{OC}, \% \mathrm{TN}, \mathrm{mg} / \mathrm{kg} \mathrm{P}, \mathrm{meq} / 100 \mathrm{~g} \mathrm{~K}, \mathrm{CEC}$, and Ex. acidity stands for power of hydrogen, percent of organic carbon, percent of total nitrogen, milligram per kilogram of Phosphorus, milli equivalent per 100 gram potassium, Cation exchangeable capacity, and exchangeable acidity respectively.

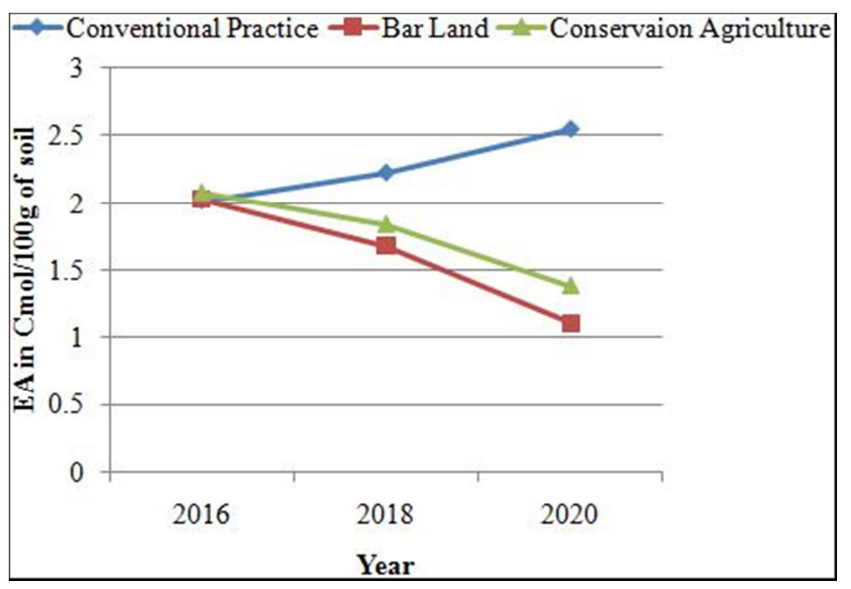

Figure 6. Effect of three agricultural practices and year interaction on soil exchangeable acidity at $0-30 \mathrm{~cm}$ soil depth.

As figures 2 to 6 data showed that the soil analysis of $\mathrm{pH}$, $\mathrm{OC}, \mathrm{TN}, \mathrm{CEC}$, and $\mathrm{K}$ result recorded increasingly through year in bare land and conservation agriculture (Zero tillage): Soybean-Maize rotation with residue retained practice and the conventional one was decreased while increased years of practices. Figure 7 also showed that the soil laboratory result in meq $/ 100 \mathrm{~g}$ soil of exchangeable acidity decreased within analysis years intervals in both bare land and zero tillage conservational practices, and increased acidity for the conventional agricultural practice. Percent of organic carbon, total nitrogen, $\mathrm{pH}$, and $\mathrm{CEC}$ have positive correlation between them. Although the conservational practice result showed positive impact on soil nutrient, the data indicated less than the recommended amount of nutrient for farm land soil. This study confirm the Ethiopian agricultural transformation agency result [30].

\section{Conclusion}

In conclusion, Conservation agribusiness practices improve sloppy and degraded land soil chemical properties in long run as a result of advancement of soil structure and chemical composition. The findings of this research demonstrates that a soil test is imperative to improve crop production, ensure environment from defilement by runoff and leaching of overabundance fertilizers, help within the determination of plant culture problems, improve the nutritional balance of the growing media and save money by applying prescribed sum of input required. The higher amount of SOC in surface soil layer in conservation agriculture is a result of higher accumulation of crop residue on the surface which also increase the availability of mineral nutrition. The results of the research carried out also; the soil of an area which was treated by integrated soil conservation practices has shown a significant chemical properties improvement than the soil of the conventional practice land.

In general, the main chemical properties crucial for plants development such as soil organic carbon, $\mathrm{pH}$, percent of total nitrogen, potassium, and phosphorus concentrations in the conserved lands were maintained by soil conservation practices were found to be significantly higher than the concentration degraded by conventional agricultural practices land. The research result indicates that the soil conservation practices have positive impacts in improving the fertility status of the eroded lands.

\section{Recommendations}

Ethiopian agricultural transformation agency investigation showed in Western Ethiopia, such as Assosa there is a problem farm land soil acidity. The acidity and infertile soils are formed by conventional practices and soil erosion. The result of this study suggested that using conservation agriculture can be rehabilitated in to healthy soil and might has a positive impact on soil quality for increment of productivity; especially for eroded and degraded farm lands. 


\section{Acknowledgements}

The author would like to thank to Ethiopian Institute of Agricultural Research (EIAR), and Assosa Agricultural research Center (AsARC) for its general offer of chemicals, instruments and research budget allocation during this work.

\section{References}

[1] Eswaran H, Lal R and Reich, P. F. (2001). Land degradation: An overview. In: Response toLandDegradation, Bridges EM, I.D. Hannam, L.R. Oldeman, F.W.T. PenningdeVries, J. S. Scherr and S. Sombatpanit (eds). Science Publisher, Inc.: Enfield, NH; 20-35.

[2] Hurni H., (1993). Land degradation, famines and resource scenarios in Ethiopia. In World Soil Erosion and Conservation, Pimentel D (ed.).Cambridge University Press: Cambridge; 27-62.

[3] Nebel, B. J. and Wright, R. T. (1993).Environmental Science. Prentice Hall, New Jersey

[4] Hudson, N. W., (1995). Soil Conservation $3^{\text {rd }}$ edition. Iowa State University Press: Ames, IA. 320pp.

[5] Jat, R. A., Wani, S. P. and Sahrawat, K. L. (2012). Conservation agriculture in the semi-arid tropics: prospects and problems. Adv. Agron. 117: 191-273.

[6] Naresh R. K.; Dhaliwal, S. S.; Kumar D.; Tomar, S. S.; Misra, A. K.; Singh S. P., Kumar, P.; Kumar V; Gupta R. K. (2014). Tillage and Rice-Wheat Cropping Systems Influences on Soil Physical Properties; water balance and Wheat Yield under Irrigated Conditions. AJAR (32): 2463- 2474.

[7] Doran, J.W.; Safley, M. (1997). Defining and assessing soil health and sustainable productivity. In Biological Indicators of Soil Health; Pankhurst, C.E., Doube, B.M., Gupta, V.V.S.R., Eds.; CAB International: Wallingford, UK.

[8] Gugino, B.K.; Idowu, O.J.; Schindelbeck, R.R.; van Es, H.M.; Wolfe, D.W.; Moebius-Clune, B.N.; Thies, J.E.; Abawi, G.S. Cornell (2009). Soil Health Assessment Training Manual, 2nd ed.; Cornell University, College of Agriculture and Life Science: Ithaca, NY, USA

[9] Teklu Erkossa., (2011). Tillage effects on physical qualities of vertisol in the central highlands of Ethiopia. African Journal of Environmental Science and Technology 5: 008-1016.

[10] Nunes, J. S.; Araujo, A. S. F.; Nunes, L. A. P. L.; Lima, L.M.; Carneiro, R. F. V.; Tsai, S. M.; Salviano, A. A. C. (2012). Land degradation on soil microbial biomass and activity in Northeast Brazil. Pedosphere, 22, 88-95.

[11] Habig, J.; Hassen, A.I.; Swart, A. (2015). Application of microbiology in conservation agriculture. In Conservation Agriculture; Farooq, M., Kadambot, H.M., Eds.; Springer International Publishing: Cham (ZG), Switzerland; pp. 525-557.

[12] Johansson, J.F.; Paul, L.R.; Finlay, R.D. (2004). Microbial interactions in the mycorrhizosphere and their significance for sustainable agriculture (Minireview). FEMS Microbiol. Ecol. $48,1-13$.

[13] Karlen, D.L.; Eash, N.S.; Unger, P.W. (1992). Soil and crop management effects on soil quality indicators. Am. J. Altern.
Agric. 7, 48-55.

[14] Galantini, J.A., Landriscini, M. R., Iglesias, J. O., Miglierina, A. M. and Rosell, R. A. (2000). The effects of crop rotation and fertilization on wheat productivity in the Pampean semiarid region of Argentina 2. Nutrient balance, yield and grain quality. Soil \& Tillage Research 53: 137-144.

[15] Hulugalle, N. R., Entwistle, P. C., Weaver, T. B., Scott, F. and Finlay, L. A. (2000). Cotton-based rotation systems on a sodic Vertosol under irrigation: effects on soil quality and profitability. Aust. J. Exp. Agr. 42: 341-349.

[16] Reichert, J. M, Suzuki, L. E. A. S., Reinert, D. J., Horn, R. and Hakansson, I. (2009). Reference bulk density and critical degree-of-compactness for no-till crop production in subtropical highly weathered soils. Soil \& Tillage Research 102: 242-254.

[17] McKenzie NJ, Jacquier DJ, Isbell RF, Brown KL (2004) Australian Soils and Landscapes: An Illustrated Compendium. CSIRO Publishing: Collingwood, Victoria.

[18] Black, C.A. (Ed) (1965). Determination of exchangeable Ca, $\mathrm{Mg}, \mathrm{K}, \mathrm{Na}, \mathrm{Mn}$ and effective cations exchange capacity in soil. Methods of soil analysis agro. No. 9 part 2 American Society of Agronomy, Madison, Wisconsin, 1122 pp.

[19] Lal, R. (2003). Soil erosion and the global carbon budget. Environment International; 29: 437-450.

[20] Six, J., Guggenberger, G., Paustian, K., Haumaier, L., Elliott, E.T., and Zech, W. (2001). Sources and composition of soil organic matter fractions between and within soil aggregates. Eur. J. Soil Sci. 52: 607-618.

[21] Paustian, K., Six, J., Elliott, E.T. and Hunt, H.W. (2000). Management options for reducing $\mathrm{CO}_{2}$ emissions from agricultural soils. Biogeochem., 48 (1): 147-163.

[22] Bray R.H., Kurz L.T. (1945). Determination of total, organic and available forms of phosphorous in soil. Soil Sci. 59: 39-45 Ankerman, D, Large R. (SD) Agronomy handbook, soil and plant analysis, A and L. Agricultural Laboratories. Memphis, USA.

[23] Black, C.A. (1965). Determination of exchangeable Ca, Ma, $\mathrm{K}, \mathrm{Na}, \mathrm{Mn}$ and effective cations exchange capacity in soil. Methods of soil analysis agro. No. 9 part 2 Amer. Soc. Agronomy, Madison, Wisconsin.

[24] Hazelton PA, Murphy BW (2007). Interpreting Soil Test Results: What Do all the numbers mean? CSIRO Publishing: Melbourne.

[25] AOAC (2000). Official Methods of Analysis. 17th Edition, The Association of Official Analytical Chemists, Gaithersburg, MD, USA. DOI: 10.4236/oalib.1105505.

[26] Hach Company (1992). Water Analysis Handbook. 2nd Edition, Hach Company, Loveland, Colorado, USA, 303, 6693050 .

[27] Ngwira, AR, Aune JB, Mkwinda S (2012). On-farm evaluation of yield and economic benefit of short-term maize legume intercropping systems under conservation agriculture in Malawi. Field Crops Res. J. 132: 149-157.

[28] McCauley A, Jones C, Olson-Rutz K (2017). Soil pH and Organic Matter. Nutrient Management Module Number 8. $\mathrm{http} / / /$ landresources.montana.edu/mm/document/MM8. 
[29] Verhulst, N., Govaerts, B., Verachtert, E., CastellanosNavarrete, A., Mezzalama, M., Wall, P., Deckers, J. and Sayre, K.D. (2010). Conservation agriculture, improving soil quality for sustainable production systems. Advances in soil science: food security and soil quality; pp. 137-208.

[30] Agricultural Transformation Agency (ATA) (2013) and (209).
Status of soil resources in Ethiopia and priorities for sustainable management. Ethiopian agricultural transformation agency. In: Global Soil partnership (GSP) for eastern and southern Africa, Nairobi, Kenya. Available at: http://www.fao.org/fileadmin/user_upload/GSP/docs/Southeas t_partnership /Ethiopia.pdf. 